\title{
PENGARUH SUBTITUSI KEDELAI DENGAN FERMENTASI TEPUNG DAUN LAMTORO PADA PAKAN UDANG VANAME (Litopenaeus vannamei) TERHADAP NILAI KECERNAAN PROTEIN DAN KECERNAAN ENERGI
}

\section{Substitution Effect of Soybean with Fermentation Lamtoro Leaves for White Shrimp (Litopenaeus vannamei) Feed on Digestibility Protein and Energy}

\author{
Brian Zuliyan ${ }^{1}$, Agustono ${ }^{2}$ dan Woro Hastuti Satyantini ${ }^{2}$. \\ ${ }^{1}$ Program Studi Budidaya Perairan, Fakultas Perikanan dan Kelautan, Universitas Airlangga, Surabaya \\ ${ }^{2}$ Departemen Manajemen Kesehatan Ikan dan Budidaya Perairan, Fakultas Perikanan dan Kelautan, Universitas \\ Airlangga, Surabaya \\ Email : fpk@unair.ac.id
}

\begin{abstract}
Abstrak
Udang vaname mulai dibudidayakan di Indonesia sejak tahun 2001. Kendala bagi pembudidaya yaitu biaya pakan pada udang dapat mencapai 50\% dari biaya produksi sehingga untuk mengatasi tingginya harga pakan, maka perlu pakan alternatif berprotein tinggi dengan harga murah. Daun lamtoro merupakan salah satu leguminosa yang dapat digunakan sebagai bahan pakan tambahan karena mempunyai kadar protein yang cukup tinggi dan mudah dicerna. Kecernaan merupakan proses usus mencerna makanan dan penyerapan nutrisi pada pakan yang diberikan. Daya cerna pada ikan menggambarkan sebagian kecil dari nutrisi atau energi dalam bahan yang tidak termakan dan diekskresikan dalam bentuk feses.

Penelitian ini bertujuan untuk mengetahui pengaruh pemanfaatan fermentasi tepung daun lamtoro sebagai subtitusi kedelai udang vaname (Litopenaeus vannamei) terhadap nilai kecernaan protein dan kecernaan energi. Metode penelitian yang digunakan adalah eksperimental menggunakan Rancangan Acak Lengkap (RAL) dengan 4 perlakuan dan 5 ulangan. Perlakuan P0 (kadar fermentasi tepung daun lamtoro 0\%), P1 (kadar fermentasi tepung daun lamtoro 10\%), P2 (kadar fermentasi tepung daun lamtoro 20\%) dan P3 (kadar fermentasi tepung daun lamtoro 30\%). Parameter yang diukur adalah nilai kecernaan protein dan kecernaan energi. Analisa data menggunakan ANOVA (Analysis of variance) dan dilanjutkan dengan Uji Jarak Berganda Duncan.

Hasil penelitian menunjukkan bahwa nilai kecernaan protein dan kecernan energi yang tidak jauh berbeda $(\mathrm{P}>0.05)$. Hal ini menunjukkan bahwa fermentasi tepung daun lamtoro dianggap mampu menggantikan bungkil kedelai sebagai bahan dasar pembuatan ransum pakan udang vaname dengan kadar fermentasi tepung daun lamtoro hingga 30\%. Pemanfaatan fermentasi tepung daun lamtoro sebagai substitusi kedelai pada pakan udang vaname tidak memiliki pengaruh yang berbeda terhadap nilai kecernaan protein dan nilai kecernaan energi.
\end{abstract}

Kata kunci: Udang Vaname, Fermentasi, Kecernaan Protein dan Kecernaan Energi

Abstract

Vaname shrimp began to be cultivated in Indonesia since 2001. Feed is a crucial component to the success of shrimp farming. High and low feed prices are determined by the size of the protein in the feed. Obstacle for farmers is the cost of feed on the shrimp can reach 50\% of the cost of production so as to address the high price of feed, it is necessary to feed high protein alternative with low price. Lamtoro leaf is one of the legume that can be used as an additional feed material because it has a high protein content and easy to digest. Intestinal digestibility is the process of digesting food and absorption of nutrients in the feed. Feed digestibility is influenced by factors of physics and chemistry of food, type of food, the nutritional content of food, the amount of digestive enzymes of fish, the size of the fish, as well as physical and chemical properties of waters. Digestibility in fish depict a fraction of the nutrients or energy in a material that is not consumed and excreted in the form of feces.

This aim of this research is to know about the effects of the use of fermented flour as a substitute soybean leaves lamtoro vaname shrimp (Litopenaeus vannamei ) against the value of digestibility of protein and energy digestibility. The method used was experimental use completely randomized design (CRD) with 4 treatments and 5 replications. Treatment P0 (fermented flour content of leaves lamtoro $0 \%$ ), P1 (fermented flour content of leaves lamtoro 10 \%), P2 (content of fermented flour lamtoro leaves $20 \%$ ) and P3 (fermented 
flour content of leaves lamtoro $30 \%$ ). Measured parameter is the value of protein digestibility and energy digestibility. Data were analyzed using ANOVA (analysis of variance ) and continued with Duncan Multiple Range Test .

The results showed that the digestibility of protein and energy kecernan not much different $(\mathrm{P}>0.05)$. This indicates that the fermented flour leaves lamtoro deemed capable of replacing soybean meal as the manufacture shrimp feed rations with levels of fermentation vaname lamtoro leaf meal up to $30 \%$. Utilization of fermented flour as a substitute for soybean leaf lamtoro in shrimp feed vaname not have a different effect on the value of protein digestibility and energy digestibility values.

Keywords: White Shrimp, Fermentation, Protein Digestibility and Energy Digestibility

\section{PENDAHULUAN}

Udang vaname mulai dibudidayakan di Indonesia sejak tahun 2001 (Adiwidjaya dkk., 2008). Pakan merupakan komponen yang sangat penting untuk menentukan keberhasilan budidaya udang (Soemardjati dan Suriawan, 2007). Kendala bagi pembudidaya yaitu biaya pakan pada udang dapat mencapai 50\% dari biaya produksi sehingga untuk mengatasi tingginya harga pakan, maka perlu pakan alternatif berprotein tinggi dengan harga murah.

Salah satu bahan pakan yang dapat dijadikan sebagai bahan pakan sumber protein nabati adalah daun lamtoro. Daun lamtoro merupakan salah satu leguminosa yang dapat digunakan sebagai bahan pakan tambahan karena mempunyai kadar protein sekitar 23,83 \% (Putri, 2012). Jones (1979) menyatakan bahwa tingkat pemecahan protein pada daun lamtoro di dalam lambung relatif rendah sehingga merupakan sumber protein yang baik.

$$
\text { Daun lamtoro mempunyai }
$$

kandungan serat kasar yang cukup tinggi yaitu 21,58 \% (Putri, 2012) sehingga sebelum dicampurkan sebagai tambahan pakan, daun lamtoro harus mengalami proses fermentasi terlebih dahulu. Prinsip kerja dari fermentasi yakni bahan-bahan yang tidak dapat dicerna seperti selulosa mengalami proses pemecahan, hemiselulosa menjadi gula sederhana yang mudah dicerna dengan bantuan mikroorganisme (Parakkasi, 1995). Hasil fermentasi diharapkan dapat meningkatkan kualitas bahan pakan yang akan digunakan sebagai campuran pakan dan mampu mempercepat pertumbuhan (Widiastuti, 2007).

Kecernaan merupakan indikator dari kualitas pakan yang diberikan terhadap udang. Apabila kecernaannya rendah maka nilai manfaatnya akan menjadi rendah, sebaliknya apabila kecernaannya tinggi maka nilai manfaatnya akan menjadi tinggi (Abun, 2007). Keseimbangan antara energi dan kadar protein sangat penting untuk laju pertumbuhan, Jika energi dalam pakan rendah daripada kebutuhan energi ikan, maka ikan akan memanfaatkan protein sebagai sumber energi untuk pemeliharaan fungsi biologis (Halver, 1989). Penambahan protein ke dalam pakan bertujuan untuk menambahkan asam amino esensial dalam pakan buatan. Kecernaan protein masing-masing bahan pakan berbeda-beda. Energi diperlukan dalam pengendalian reaksi kimia untuk membuat jaringan baru, mempertahankan tekanan osmotik dan keseimbangan garam, menyimpan dan mengeluarkan cairan tubuh (Smith, 1989).

Berdasar pada latar belakang diatas, maka dilakukan penelitian ransum pakan udang vaname dengan pemanfaatan fermentasi daun lamtoro sebagai subtitusi kedelai terhadap nilai kecernaan protein dan kecernaan energi udang vaname (Litopenaeus vannamei).

\section{METODOLOGI \\ Waktu dan Tempat}

Penelitian ini dilaksanakan pada bulan Januari - Februari 2015 di Laboratorium Pendidikan Fakultas Perikanan dan Kelautan Universitas 
Airlangga Surabaya. Analisis proksimat dilakukan di Laboratorium Kimia Universitas Muhamadiyah Malang.

\section{Materi Penelitian}

Peralatan Penelitian

Alat-alat yang digunakan dalam penelitian adalah akuarium, filter, seser/serok, selang, penggilingan, pengayakan, timbangan, baskom, alat pencetak pellet, oven, plastik, gunting, kertas, loyang, $\mathrm{pH}$ meter, termometer, refraktometer, DO meter, ammonia test kit.

\section{Bahan Penelitian}

Bahan yang digunakan dalam penelitian ini adalah udang vaname, daun lamtoro, kedelai, dedak halus tepung ikan, tepung jagung, vitamin, $\mathrm{Cr}_{2} \mathrm{O}_{3}$ (Cromium Trioxyde) bakteri Lactobacillus sp., Nitrosomonas sp., Bacillus sp., Trichoderma sp., larutan fermentor dan klorin.

\section{Metode Penelitian}

Metode penelitian adalah eksperimental. Rancangan yang digunakan dalam penelitian ini adalah Rancangan Acak Lengkap (RAL) dengan empat perlakuan dan lima ulangan. Perlakuan pada penelitian ini adalah sebagai berikut: $\mathrm{P}_{0}$ : pakan dengan dosis $40 \%$ kedelai $+0 \%$ fermentasi tepung daun lamtoro.

$\mathrm{P}_{1}$ : pakan dengan dosis $30 \%$ kedelai + $10 \%$ fermentasi tepung daun lamtoro.

$\mathrm{P}_{2}$ : pakan dengan dosis $20 \%$ kedelai + $20 \%$ fermentasi tepung daun lamtoro.

$\mathrm{P}_{3}$ : pakan dengan dosis $10 \%$ kedelai + $30 \%$ fermentasi tepung daun lamtoro.

\section{Prosedur Kerja}

\section{Pembuatan Fermentasi Tepung Daun Lamtoro}

Daun lamtoro yang diambil dari pohon dipisahkan terlebih dahulu antara batang dan daunnya. Bagian daun yang diambil adalah daun yang terletak pada bagian ujung hingga tengah batang, Daun lamtoro yang telah direndam kemudian dikeringkan melalui sinar matahari langsung selama satu hari setelah kering digiling menggunakan mesin penggiling sampai menjadi tepung. Tepung direndam dengan air selama satu hari untuk menghilangkan kadar mimosin daun lamtoro. Tepung kemudian disaring kemudian dikeringkan dengan suhu 27-30 $\mathrm{C}$, setelah itu tepung daun lamtoro dimasukkan kedalam kantong plastik. Tiap kantong diisi tepung sebanyak 50 gram. Proses pencampuran Tepung Daun Lamtoro dengan Probiotik yang mengandung bakteri Lactobacillus sp., Nitrosomonas sp., Bacillus sp. dan Trichoderma sp. dituang ke dalam baki untuk diaduk secara homogen dengan larutan fermentor. Larutan fermentor dibuat dengan cara dengan mencampurkan aquades $10 \mathrm{ml}$ dan tetes tebu 3\% dari jumlah berat bahan yang akan difermentasi (Widayati dan Widalestari, 1996) sampai merata kemudian ditambahkan probiotik dengan dosis 8\% atau sebanyak $4 \mathrm{ml}$. Tepung daun lamtoro dan probiotik yang telah tercampur kemudian dimasukkan ke dalam kantong plastik dan dilubangi 0,5 cm kemudian didiamkan pada suhu ruang selama tujuh hari (Putri, 2012).

\section{Pembuatan Pakan Perlakuan}

Bahan pakan yang ditimbang
sesuai perlakuan formulasi yang dikehendaki. Tepung daun lamtoro yang telah ditimbang sesuai perlakuan lalu dicampur dengan kedelai sesuai dosis perlakuan $\mathrm{P}_{1}, \mathrm{P}_{2}$ dan $\mathrm{P}_{3}$. Bahan pakan yang telah jadi ditimbang dengan berat yang sama kemudian ditambahkan dengan $\mathrm{Cr}_{2} \mathrm{O}_{3}$ (Cromium Trioxyde) 0,5\% (NRC, 1993) sebagai penanda dalam uji kecernaan. Ransum pakan yang telah jadi kemudian dimasukan ke dalam loyang dan dikukus selama 10 menit. Setelah pakan siap, kemudian dicetak dengan menggunakan mesin pellet atau mesin penggiling daging. Pellet yang sudah setengah jadi kemudian dikeringkan dengan suhu $60^{\circ} \mathrm{C}$ selama 24 jam dengan menggunakan oven, setelah di oven selama 24 jam pellet siap untuk digunakan. Pakan 
uji adalah pakan buatan berbentuk pellet kering yang ukurannya disesuaikan dengan ukuran bukaan mulut udang.

\section{Persiapan Hewan Uji}

Udang yang digunakan dalam penelitian ini adalah udang vaname (Litopenaeus vanamei) dengan berat berat rata-rata 8-9 g/ekor yang digunakan adalah udang vaname yang sehat dan tidak terserang penyakit serta tidak cacat fisik.

\section{Pengamatan Kecernaan}

Pengamatan nilai kecernaan digunakan bahan indikator yang dapat bertahan untuk tidak rusak atau tercerna oleh saluran pencernaan. Bahan yang umumnya dipakai sebagai indikator kecernaan adalah $\mathrm{Cr}_{2} \mathrm{O}_{3}$ (Cromium Trioxyde). $\quad \mathrm{Cr}_{2} \mathrm{O}_{3}$ (Cromium Trioxyde) akan dikonsumsi ikan (udang) melalui sistem pencernaan dan terlihat dalam feses (NRC 1993). Untuk mengukur nilai kecernaan pakan ditambahkan dengan $\mathrm{Cr}_{2} \mathrm{O}_{3}$ 0,5\%. Menurut Watanabe (1988) Banyaknya kandungan $\mathrm{Cr}_{2} \mathrm{O}_{3}$ yang digunakan dalam formulasi pakan adalah sebesar 0,5-1,0\%. Pengukuran kecernaan dilakukan selama 15 hari. Pakan diberikan tiga kali dalam sehari pada jam 09.00, 12.00 dan 15.00 WIB. Pada hari ke 5 sampai ke 15 feses udang mulai dikumpulkan. Pengambilan feses dilakukan dengan cara penyiponan. Feses yang terkumpul kemudian disimpan dalam botol film dan disimpan dalam lemari pendingin (freezer) untuk menjaga kesegarannya. Feses kemudian dikeringkan menggunakan oven dengan suhu sekitar $60^{\circ} \mathrm{C}$ selama 24 jam. Analisis dengan menggunakan Cromium oxide $\left(\mathrm{Cr}_{2} \mathrm{O}_{3}\right)$ dilakukan di Laboratorium Kimia Universitas Muhammadiyah Malang.

\section{Kecernaan Protein}

Nilai kecernaan protein dihitung berdasarkan persamaan (Takeuchi, 1988):

Kecernaan Protein $(\%)=100 \mathrm{x}\left[1-\frac{\mathrm{a}}{\mathrm{a}^{\gamma}} \mathrm{x} \frac{\mathrm{b}}{\mathrm{b}^{f}}\right]$ Keterangan:

$$
\begin{aligned}
& \mathrm{a}^{\prime}=\% \mathrm{Cr}_{2} \mathrm{O}_{3} \text { dalam pakan } \\
& \mathrm{a}=\% \mathrm{Cr}_{2} \mathrm{O}_{3} \text { dalam feses } \\
& \text { b'= \% protein dalam pakan } \\
& \text { b= \% protein dalam feses }
\end{aligned}
$$

\section{Kecernaan Energi}

Kecernaan Energi (\%): $\quad$ [Energi tercerna (kkal) / Energi dalam pakan (kkal)] x $100 \%$

Keterangan :

Energi tercerna (kkal) : Energi dalam pakan (kkal) - Energi feses (kkal) $\times \frac{\mathrm{n}}{\mathrm{n}^{f}}$

$\mathrm{n}=\mathrm{mg} \mathrm{Cr}_{2} \mathrm{O}_{3} / \mathrm{g}$ dalam feses

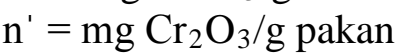

\section{HASIL DAN PEMBAHASAN Hasil}

Hasil pengamatan nilai kecernaan protein setelah dilakukan pengumpulan feses selama 15 hari tersaji pada Tabel 1.

Tabel 1. Rata-rata nilai kecernaan protein pada masing-masing perlakuan.

\begin{tabular}{|c|c|c|}
\hline Perlakuan & $\begin{array}{c}\text { Rata-rata Nilai } \\
\text { Kecernaan (\%) } \\
\pm \text { SD }\end{array}$ & $\begin{array}{l}\text { Transformasi( } \sqrt{ }) \pm \\
\text { SD }\end{array}$ \\
\hline P0 & $91,02 \pm 0,05$ & $9,54 \pm 0,03$ \\
\hline P1 & $91,22 \pm 1,13$ & $9,55 \pm 0,06$ \\
\hline P2 & $91,41 \pm 2,07$ & $9,56 \pm 0,07$ \\
\hline P3 & $91,57 \pm 2,68$ & $9,67 \pm 0,11$ \\
\hline
\end{tabular}

Keterangan: $\mathrm{P} 0=40 \%$ kedelai $+0 \%$ FTDL; $\mathrm{P} 1=$ $30 \%$ kedelai $+10 \%$ FTDL ; P2 $=20 \%$ kedelai + 20\% FTDL P3=10\% kedelai + 30\% FTDL ; SD = Standart Deviasi

Berdasarkan Tabel 1 dapat diketahui bahwa rata-rata nilai kecernaan diperoleh pada setiap perlakuan dengan dosis yang telah ditentukan menunjukan hasil yang tidak jauh berbeda. Hasil analisis ragam menunjukkan perlakuan $\mathrm{P0}$ (kadar fermentasi tepung daun lamtoro 0\%), P1 (kadar fermentasi tepung daun lamtoro 30\%), P2 (kadar fermentasi tepung daun lamtoro 20\%) dan P3 (kadar fermentasi tepung daun lamtoro 10\%) memiliki nilai kecernaan protein yang tidak berbeda nyata $(\mathrm{P}>0,05)$. 
Hasil pengamatan nilai kecernaan energi setelah dilakukan pengumpulan feses selama 15 hari tersaji pada Tabel 2.

Tabel 2. Rata-rata nilai kecernaan energi pada masing-masing perlakuan.

\begin{tabular}{|c|c|c|}
\hline Perlakuan & $\begin{array}{c}\text { Rata-rata Nilai } \\
\text { Kecernaan (\%) } \pm \\
\text { SD }\end{array}$ & $\begin{array}{c}\text { Transformasi ( } \\
\pm \text { SD }\end{array}$ \\
\hline P0 & $90,46 \pm 0,51$ & $9,51 \pm 0,03$ \\
\hline P1 & $90,85 \pm 0,75$ & $9,53 \pm 0,04$ \\
\hline P2 & $91,08 \pm 1,45$ & $9,54 \pm 0,08$ \\
\hline P3 & $91,25 \pm 1,15$ & $9,55 \pm 0,10$ \\
\hline
\end{tabular}

Keterangan: $\mathrm{P} 0=40 \%$ kedelai $+0 \%$ FTDL; P1 $=$ $30 \%$ kedelai $+10 \%$ FTDL ; P2 $=20 \%$ kedelai + 20\% FTDL P3=10\% kedelai + 30\% FTDL ; SD = Standart Deviasi

Berdasarkan Tabel 2 dapat diketahui bahwa rata-rata nilai kecernaan diperoleh pada setiap perlakuan dengan dosis yang telah ditentukan menunjukan hasil yang tidak jauh berbeda. Hasil analisis ragam menunjukkan perlakuan P0 (kadar fermentasi tepung daun lamtoro 0\%), P1 (kadar fermentasi tepung daun lamtoro 10\%), P2 (kadar fermentasi tepung daun lamtoro 20\%) dan P3 (kadar fermentasi tepung daun lamtoro 30\%) memiliki nilai kecernaan energi yang tidak berbeda nyata $(\mathrm{P}>0,05)$.

\section{Pembahasan}

Kecernaan protein adalah nilai kandungan protein yang terdapat pada formulasi pakan yang diberikan dan tercerna oleh tubuh. Kecernaan protein berfungsi untuk mengetahui berapa besar kandungan protein dari pakan yang diserap oleh tubuh. Perlakuan P0 (kadar fermentasi tepung daun lamtoro 0\%), P1 (kadar fermentasi tepung daun lamtoro 10\%) , P2 (kadar fermentasi tepung daun lamtoro 20\%) dan P3 (kadar fermentasi tepung daun lamtoro 30\%) memperlihatkan nilai kecernaan protein yang tidak jauh berbeda $(\mathrm{P}>0.05)$. Hal ini menunjukkan bahwa fermentasi tepung daun lamtoro dianggap mampu menggantikan kedelai sebagai bahan dasar pembuatan ransum pakan udang vaname dengan kadar fermentasi tepung daun lamtoro hingga 30\%.

Kecernaan merupakan indikator untuk mengetahui kemampuan ikan dalam mencerna pakan yang diberikan (Widyasunu dkk., 2013). Menurut Halver (1989), energi didapatkan dari proses kimia dalam tubuh dimana semua nutrisi yang didapat dari makanan dipecah kemudian digunakan dalam pembentukan energi.

Berdasarkan penelitian substitusi fermentasi tepung daun lamtoro terhadap kedelai pada pakan udang vaname menunjukkan hasil yang tidak berpengaruh nyata $(\mathrm{P}>0,05)$ terhadap nilai kecernaan energi. Perlakuan P0, P1, P2 dan P3 menunjukkan nilai kecernaan energi yang relatif sama. Setiap perlakuan memiliki rata-rata nilai kecernaan energi lebih dari $90 \%$ sehingga pakan yang mengandung fermentasi daun lamtoro memiliki kualitas yang dapat menggantikan kedelai. Menurut Silva (1989) kemampuan ikan (udang) dalam memanfaatkan komponen pakan selain protein memberikan andil yang cukup besar dalam kecernaan energi (protein sparing effect) dengan menggunakan lemak dan kabohidrat sebagai sumber energi.

\section{KESIMPULAN DAN SARAN Kesimpulan}

Pemanfaatan fermentasi tepung daun lamtoro sebagai substitusi kedelai pada pakan udang vaname tidak memiliki pengaruh yang berbeda terhadap nilai kecernaan protein dan energi.

\section{Saran}

Pemanfaatan fermentasi tepung daun lamtoro sebagai substitusi kedelai pada pakan udang vaname terhadap nilai kecernaan protein mampu menggantikan kedelai dengan kadar sebesar 30\% dan nilai kecernaan energi dengan kadar sebesar $10 \%$. Berdasarkan pengamatan selama penelitian dan penjelasan singkat di atas, 
maka penelitian ini dilakukan guna menambahkan informasi tentang pemanfaatan fermentasi tepung daun lamtoro sebagai pengganti kedelai pada ransum pakan udang vaname kepada pembudidaya.

\section{DAFTAR PUSTAKA}

Abun. 2007. Pengukuran Nilai Kecernaan Ransum yang Mengandung Limbah Udang Windu Produk Fermentasi pada Ayam Broiler. Fakultas Peternakan Universitas Padjajaran. Bandung. Hal 2.

Adiwidjaya, D., Supito dan I, Sumantri. 2008. Penerapan Teknologi Budidaya Udang Vaname $L$. vannamei Semi Intensif pada Lokasi Tambak Salinitas Tinggi. Media Budidaya Air Payau Perekayasaan, (7): 54-72.

Halver, J. E. 1989. Fish Nutrition. 2nd editions Academic Press. London. Pp. 1-23.

Jones, R.J . 1979. The value of Leucaena leucocephala as a feed for ruminants in tropics. World Anim . Rev ., No . 31 . Hal 13-23

NRC (National Research Council).1993. Nutrient Requirement of Fish. DC. National Academic. Washington. pp. 48.

Parakkasi, A. 1995. Ilmu Nutrisi dan Makanan Ternak Ruminan. Universitas Indonesia. Jakarta.

Putri, D. R. 2012. Kandungan Bahan Kering, Serat Kasar dan Protein Kasar pada Daun Lamtoro (Leucaena glauca) yang difermentasi dengan Probiotik sebagai pakan ikan. Skripsi. Program Studi Budidaya Perairan. Fakultas Perikanan dan Kelautan Universitas Airlangga. Hal 61.

Smith, R. R. 1989. Nutritinal Energetics. In Fish Nutrition. J. E. Halver (eds). Academic Press, Inc. New York. 1-28pp.

Soemardjati W, Suriawan A. 2007.Petunjuk teknis budidaya udang vaname (Litopenaeus vannamei) di Tambak. Departemen Kelautan dan Perikanan. Direktorat Jenderal Perikanan Budidaya. Balai Budidaya Air Payau. Situbondo. 30 hal.

Watanabe, T. 1988. Fish Nutrition and Mariculture. Departement of Aquatic Biosciences Tokyo Uniiversity of Fisheries, JICA. pp 233.

Widayati, E. dan Widalestari, Y., 1996. Limbah untuk Pakan Ternak. Trubus.

Widiastuti, R.R. 2007. Formulasi pakan buatan dengan teknologi fermentasi pada budidaya ikan nila (Oreochromis niloticus). Jurusan SITH-ITB.Bandung. hal. 15-17.

Widyasunu, C. A., I. Samidjan, dan D. Rachmawati. 2013. Subtitusi tepung ikan dengan tepung cacing (Lumbricus rubellus) dalam pakan buatan terhadap pertumbuhan danefisiensi pemanfaatan pakan kerapu macan (Epinephelus fuscoguttatus). Journal of Aquaculture Management and Technology, 2 (1) : 38-51. 